\title{
Cep Telefonu Sektöründe Müşteri Marka Memnuniyetinin Öncülleri ve Sonuçları
}

\author{
Süleyman Can YILDIRIR ${ }^{1}$ ve Lütfi SÜRÜCÜ²
}

$\ddot{O} z$

Çalışmada, genç cep telefonu kullanıcılarında marka güveni ve marka imajının müşteri marka memnuniyetine etkisi, müşteri marka memnuniyetinin ise marka bağlllı̆̆1, marka sadakati ve satın alma niyeti üzerindeki etkisinin tespiti amaçlanmışır. Ayrıca araştırmada, marka güvenin marka bağlılığına etkisinde ve marka imajının satın alma niyetine etkisinde müşteri marka memnuniyetinin aracı rolünün tespiti de amaçlanmışır. Araştırmanın amaçları doğrultusunda hazırlanan anketler, İstanbul'da, kolayda örneklem yöntemiyle seçilen 20-30 yaş grubu yetişkin gençlere, yüz yüze anket yöntemiyle uygulanmıştır. Çalışmada, genç cep telefonu kullanıcılarının, daha pahalı olsa bile güvendiği, ihtiyaçlarını karşıladığını düşündükleri ve marka imajı olan cep telefonu markalarını tercih ettikleri tespit edilmiştir. Yapılan analizler marka güveni ve marka imajının, müşteri marka memnuniyetinin öncülü olduğunu teyit etmiştir. Bu bulgulara ilave olarak müşteri marka memnuniyeti, marka bağlllığı, marka sadakati ve satın alma niyetini olumlu yönde etkilemektedir. Çalışma neticesinde işletmelerin, ürün/hizmetlerinin fonksiyonel ya da fiziksel faydalarının yanı sıra soyut faydalara da odaklanmaları gerektiği, müşterilerde oluşan marka algısının hem işletmenin satış ve gelirlerinde hem de pazardaki yeri için önemli olduğunu değerlendirmeleri gerektiği belirlenmiştir.

Anabtar Kelimeler: Marka Güveni, Müşteri Memnuniyeti, Marka Sadakati, Tüketici, Marka İmaj1

\section{Antecedents and Consequences of Customer Brand Satisfaction on Mobile Phone Industry}

\begin{abstract}
In the study, it was aimed to determine the effect of brand trust and brand image on customer brand satisfaction in young mobile phone users, and the effect of customer brand satisfaction on brand loyalty, and purchasing intention. In addition, in the research, it was aimed to determine the mediating role of customer brand satisfaction in the effect of brand trust on brand loyalty and brand image on purchase intention. The data were collected by questionnaires prepared in line with the aims of the study, face-to-face questionnaire method from adult young people aged 20-30, who were selected by convenience sampling method in Istanbul. In the study, it was determined that young mobile phone users prefer mobile phone brands that they trust and meet their needs even if they are more expensive. Analyzes have confirmed that brand trust and brand image are the antecedents of customer brand satisfaction. In addition to these findings, customer brand satisfaction positively affects brand loyalty, brand loyalty and purchase intention. As a result of the study, it was determined that businesses should focus on intangible benefits as well as functional or physical benefits of their products, and they should evaluate that the brand perception formed in customers is important both for the sales and revenues of the business and for its place in the market.
\end{abstract}

Key Words: Brand Trust, Customer Satisfaction, Brand Loyalty, Consumer, Brand Image

\section{Atıf İçin / Please Cite As:}

Yıldırır, S. C., Sürücü, L. (2021). Cep Telefonu Sektöründe Müşteri Marka Memnuniyetinin Öncülleri ve Sonuçları. Manas Sosyal Arastırmalar Dergisi, 10(3), 1828-1840.

Geliş Tarihi / Received Date: 27.06.2020

Kabul Tarihi / Accepted Date: 11.05.2021

\footnotetext{
${ }^{1}$ Dr. - Kara Kuvvetleri Komutanlığı, canyildirir@yahoo.com

iD ORCID: 0000-0001-9161-4961

2 Dr. - European Leadership University, lutfi.surucu@elu.edu.tr

iD ORCID: 0000-0002-6286-4184
} 


\section{Giriş}

Son yıllarda homojen ve benzer özelliklere sahip ürün ve hizmetlerin artması, pazardaki rekabet ortamında işletmeleri piyasada tutunabilmeleri için bazı konularda ayrışmasına ya da farklı açılardan müşterilerine tutundurma sağlamalarına yönlendirmiştir (Morrison ve Crane, 2007, s. 419). Günümüzde hemen hemen her sektörde olduğu gibi cep telefonu sektöründe de marka rekabet avantaj1 sağlamada büyük bir etkiye sahiptir. Teknolojinin hızlı gelişimi ve endüstriyel paylaşım, işletmelerin rakip firma ürünlerindeki özellikleri kısa sürede yakalamalarına ve benzer özellikler geliştirmelerine imkân sağlamaktadır. Bu da ürün/marka tercihinde yalnızca fiyat, fonksiyonellik gibi daha çok faydacı özelliklerin yanı sıra marka güveni, bağllığı, imajı gibi daha duygusal ve sadakate dayalı tutumların da etkisinin artmasina neden olmaktadır.

Tüketici kitlesinin büyük bir kesimini oluşturan gençler, başta cep telefonu olmak üzere teknolojik ürün/hizmetlerin potansiyel müşterileri olarak görülmektedir. Son yıllarda üretilen cep telefonları, yapılan pazar araştırmalarına bağlı olarak genellikle genç müşterilerin ihtiyaç ve talepleri doğrultusunda geliştirilmekte ve pazara sunulmaktadır. Potansiyel birer müşteri olan gençler, cep telefonu sektörünün gelişiminde de katkı sağlamaktadır. Bu da gençlerin sektördeki önemini ortaya koymaktadır.

Müşteri marka memnuniyetinin öncülleri olarak "markaya olan güven, markanın imajı, markanın değeri, markanın yenilikçiliği, tüketici ilgilenimi" gibi algıların ve tüketicilerin memnuniyet düzeyleri sayilabilir (Aaker, 2009, s. 56; Özgüven, 2010, s. 144; Eren ve Erge, 2012, s. 4467; Yener, 2013, s. 93; Ulusu, 2016, s. 570; Erdil ve Uzun, 2010, s. 189-190; Aydın, 2016, s. 131; Özbek, Koç ve Doğan, 2020, s. 655). Müşteri marka memnuniyetinin sonuçları olarak ise "müşteri memnuniyeti, marka sadakati ve marka bağlllı̆ı"' sayılabilir (Bostan, Acuner ve Y1lmaz, 2005, s.187; Selvi, 2007, s.3-12).

Çoğunlukla işletmeler sadık müşteri yaratmayı hedeflemektedirler. Bu hedeflerine ulaşmak için ise hem markalarının güvenilir olmasına, imajına odaklanmak hem de müşterilerin memnuniyetini gözetmek zorundadırlar. Bu beklentiden hareketle firmalar marka güveni, marka yenilikçiliği, tüketici ilgilenimi gibi müşteri marka memnuniyetinin öncüllerinin marka bağlllğı ve marka sadakati üzerindeki etkilerini araştırma ihtiyacı duymaktadırlar (Carroll ve Ahuvia, 2006, s. 82). Bu araştırmada kullanılan değişkenler ve ilişkiler ile firmaların belirlenen sektörde ihtiyaçlarına karşılık verilebilmektedir.

Çalışmada genç yetişkinlerin cep telefonu kullanımına yönelik olarak müşteri marka memnuniyetinin öncülleri (marka güveni ve marka imajı) ve sonuçlarını (marka bağlllı̆ı, marka sadakati ve satın alma niyeti) içeren kavramsal bir model önerilmiş ve test edilmiştir. Çalışma genç cep telefonu kullanıcılarında marka güveni ve marka imajının müşteri marka memnuniyetine etkisi, müşteri marka memnuniyetinin ise marka bağllığı, marka sadakati ve satın alma niyeti üzerindeki etkisi araştırılmışır. Ayrıca araştırmada, marka güvenin marka bağlllı̆̆ına etkisinde ve marka imajının satın alma niyetine etkisinde müşteri marka memnuniyetinin aracı rolü test edilmiştir. Yapılan bu araştırma özellikle sektör temsilcilerine bir ışık tutması ve akademik çalıssmalara faydalı olması açısından önem taşımaktadır.

\section{Kavramsal Çerçeve}

\section{Marka kavramı}

Odabaşı'nın (2015, s. 36) tanımına göre marka "Satıcı ya da üreticilerin ürünlerini diğerlerinden ayırt etme adına bir kimlik tanımlaması yapılması ve bu tanımlamayı çeşitli simge ve şekillerle tarif edilmesidir". Amerikan Pazarlama Birliğine göre markanın tanımı ise "bir isim, işaret, sembol, tasarım veya hepsinin bir birleşimi olarak, bir satıcının veya satıcılar grubunun ürünlerinin/hizmetlerinin tanıtılması ve rakip firmalar için farklılık yaratmasıdır" (Kurtbaş, 2016, s. 77). Genel olarak marka tanımları incelendiğinde, başta işletmenin ya da ürünün kendisine özgü, benzersiz, kolayca tanınabilir ve akılda kalıcı sembol, isim ya da işaretin marka kavramını oluşturduğu anlaşılmaktadır. Marka, rekabetçi piyasalarda işletmelerin tanınması ve rakiplerinden ayrışmasını kolaylaştıran bir faktör olarak kullanılmaktadır.

Markanın yalnızca bir ürüne ya da hizmete verilmiş bir unvan olarak değerlendirilmesi doğru bir yaklaşım değildir. Marka pazarlama karmasının tüm bileşenlerini içeren sistematik bir sürecin sonucu ortaya çıkan bir rekabet aracıdır. Marka, müşterilerin ürün kalitesinden imajına kadar birçok boyutta beklentilerinin ne oranda olması gerektiğini önceden belirten bir etkendir (Blythe, 2001, s. 139). 
Markanın stratejik işlevleri arasında; sahiplik işareti olması, farklılaştırıcı etkisi, işlevsel bir araç rolü sayılabilir. Ayrıca sembolik olması, risk azaltıcı etkisi, tüketiciler için kısa yol aracı işlevi, yasal araçlık ve stratejik yaklaşım da işlevlerindendir (Yükselen, 2006, s. 47).

Marka, bir yandan müşterilerin ürün/hizmet hakkındaki değerlendirmelerini yansıtması diğer yandan işletmeleri arasındaki rekabetten ön plana çıkması açısından önemlidir. Tüketiciler tarafından beğenilmiş ve memnun kalınmış bir marka, işletmelerin ürettikleri farklı ürün ya da hizmetlerin de sürekli talep edilmesini ve işletmelerin yüksek ve düzenli bir satış grafiğine sahip olmasını sağlamaktadır. Bu da markanın issletme ve pazar açısından değerlendirilen diğer güç göstergeleri arasında yer almasını sağlamaktadır (Kayalı, Yereli, Soysal ve Terim, 2004, s. 181). Günümüz pazarında var olan ürün bolluğunda işletmelerin tüketiciler açısından daha fazla farkındalık yaratma çabalarında markaların önemi büyüktür. Çoğu zaman markalar sayesinde tüketiciler çok fazla ve çeşitli ürün arasından seçim yapabilmekte ve tüketiciye ürünün sahip olduğu değeri hissettirebilmektedir (Kavas, 2004, s. 18).

\section{Marka güveni}

Markaların vaatlerini yerine getirme düzeyi, sorumlulukları ile ilgili tutumları ve iyi niyet göstergeleri tüketicilerin markaya güvenmesi için gerekli kriterlerden bazılarıdır. Özellikle riskli kararlar gerektiren durumlarda, markaya olan güven karmaşık ve zor bir karar verme süreci için oldukça yardımcı olmaktadır (Doney ve Cannon, 1997, s. 42; Lewiss ve Weigart, 1985, s. 973). Markaya olan güvenin marka bağllliğına etkisini inceleyen çalışmalarda, güvenin artmasının marka bağllığının da artmasına olumlu yönde etki ettiği sonucuna ulaşılmıştır (Bernal, 2014, s. 44; Chaudhuri ve Holbrook, 2001, s. 90; Albert ve Merunka, 2013, s. 265). Literatürde yer alan ve belirtilen bulgulardan yola çıarak aşağıdaki hipotez kurgulanmışır.

\section{$H_{1}$ : Marka güveninin, marka bağhlh̆̈r üzerine olumlu ve anlamlı bir etkisi vardır.}

Marka güveni işletmeler/markalar ile tüketiciler arasında uzun sürede ve belirli kriterlere bağlı olarak gelişen bir sürecin sonucu olarak ortaya çıkmaktadır. Güven, tüketicilerin özellikle riskli anlarda markayı tercih etmeleri için önemli bir faktördür. Marka güveni, tüketici ile marka arasında gelişen ve zamana bağlı olarak kişiselleştirilen bir süreçtir. Markayı kişiselleştiren bir tüketici, o markadan uzun süre aynı kalite, performans ya da fiyat avantajını sürdürmesini bekler. Marka eğer tüketicinin beklentilerine karşılık verirse tüketicideki memnuniyet hem markaya olan bağlılı̆ını hem de tavsiye oranını artırır (Swaen ve Chumpitaz, 2008, s. 13). Literatürde yer alan ve belirtilen bulgulardan yola çıkarak aşağıdaki hipotez kurgulanmıştır.

\section{$\mathrm{H}_{2}$ : Marka güveninin, müsteri marka memnuniyeti üzerine olumlu ve anlaml bir etkisi varder.}

\section{Marka imaj1}

Marka imajı kavramında, ürünün yalnızca fiziksel varlı̆ının değil aynı zamanda ürünün psikolojik, sosyal ve duygusal etkilerinin ve özelliklerinin de dikkate alınması durumu söz konusudur. Tüketicilerin satın alma davranışlarında her ne kadar faydacı faktörlerin etkisi olsa da aynı zamanda duygusal, düşünsel ve tutumsal faktörlerin yani marka imajının da etkisi büyüktür (Değirmenci ve Durmaz, 2020, s. 270). Literatürde yer alan ve belirtilen bulgulardan yola çıkarak aşağıdaki hipotez kurgulanmıştır.

\section{$H_{3:}$ Marka imajinn, satın alma niyeti üzerine olumlu ve anlaml bir etkisi vardır.}

Marka imajının satın alma üzerindeki etkisinin araştıııldı̆̆ bazı çalışmalarda, markanın tüketiciler üzerinde özellikle kendine güven ve dışa dönüklük açısından psikolojik ve sosyal konularda olumu etki yarattığı tespit edilmiştir. Ayrıca tüketicilerin marka imajına bağlı olarak daha cesur tavırlar ve kendilerinden daha emin davranışs sergiledikleri de görülmüştür. Bu doğrultuda, marka imajı ile tüketicilerin markadan duydukları memnuniyet ve bunun sonucunda o markayı başkalarına tavsiye etmesi beklenen bir sonuçtur. (Değirmenci ve Durmaz, 2020, s. 271; Sönmez, 2010, s. 78). Literatürde yer alan ve belirtilen bulgulardan yola çıkarak aşağıdaki hipotez kurgulanmışır.

\section{$H_{4}$ : Marka imajinn, müsteri marka memnuniyeti üzerine olumlu ve anlamli bir etkisi varder.}

\section{Marka memnuniyeti}

Tüketicilerin duygusal ve mantıksal özelliklerinin markadan duydukları memnuniyete etkisinin yüksek olduğu yapılan çalışmaların birçoğunun ortak sonuçlarındandır. Tüketicilerin marka memnuniyeti oluşması için değerlendirilmesi gereken hususlar arasında; ürün/hizmetin fonksiyonel özellikleri, fiziki ve finansal durumu, sosyal açıdan kabul edilirliği ve psikolojik faydası yer almaktadır. Bu bahse konu faktörlerin olumlu bir şekilde ortaya çıkması tüketicilerin marka memnuniyetinin oluşmasının yanı sıra marka bağlılığının oluşmasını da sağlamaktadır (Düzgün, 2015, s. 45). 
Marka memnuniyeti ve marka bağlllı̆̆ı arasındaki ilişkinin incelendiği çalışmalarda, markanın ürünlerinden yüksek seviyede memnuniyet duyan tüketicilerin marka bağımlllıklarının da yüksek olduğu anlaşılmaktadır. Ayrıca tüketicilerin, gerekirse yüksek fiyat verip yine de aynı markanın ürünlerini satın alma yönünde davranış sergiledikleri de ortaya konmuştur. Marka memnuniyeti genellikle marka değerinin yüksek olduğu durumlarda, tüketicilerinin beklentilerinin karşılanma düzeyi ile doğru orantılı olarak marka bağlılı̆̆ını da etkilemektedir (Atılgan, 2017, s. 32; Onurlubaş ve Şener, 2016, s. 329; Rauyruen ve Miller, 2007, s. 29). Literatürde yer alan ve belirtilen bulgulardan yola çıkarak aşağıdaki hipotez kurgulanmıştır.

$H_{5}$ : Müsteri marka memnuniyetinin, marka bağhliğg üzerine olumlu ve anlamlı bir etkisi vardır.

\section{Marka sadakati ve bağlılığı}

Marka sadakati kavramı, müşterilerin genellikle oluşan memnuniyet ve marka bağlllı̆̆1 sebebiyle aynı markanın ürünlerini ya da hizmetlerini tercih etmesi anlamına gelmektedir. Müşteri tatmini marka sadakatini oluşturan temel unsurlar arasında yer almaktadır. İşletmeler açısından ise, sadık müşteri hem ürün satma hem de geliştirme anlamında faydalanabilecekleri tatmin olmuş müşteri demektir (Devrani, 2009, s. 409). Literatürde yer alan ve belirtilen bulgulardan yola çıkarak aşağıdaki hipotez kurgulanmıştır.

\section{$H_{6}$ : Müsteri marka memnuniyetinin, marka sadakati üzerine olumlu ve anlaml bir etkisi vardor.}

Yapılan araştırmalarda, marka bağlıllğı ile satın alma sıklğg arasında pozitif yönlü bir ilişki olduğu sonucuna ulaşılmıştır. Satın alma sıklı̆̆ ile birlikte tekrarlanan satın alma davranışı, tüketicilerin markadan memnuniyetleri ve tatminleri sonucu oluşan marka bağlllığının bir sonucu olarak ortaya çıkmaktadır (Doğru ve Koçer, 2016, s. 136; Turhan, 2009, s. 186). Ancak yapılan bazı araştırmalarda da satın alma sıklığının her zaman marka bağlılı̆̆ının bir göstergesi olmadığı, ürün/hizmet alternatiflerinin/çeşitliliğinin az olmasi, promosyonlar ya da fiyattaki ciddi bir farklılığn da satın alma siklığına etki ederek, sahte bir marka bağllliğı faktörü gibi görünebileceği anlaşılmıştır (Srinivasan, 2004, s. 622).

Marka bağlllı̆ı ve marka sadakati kavramları kısmen benzer davranışları ifade etseler de bazı konularda birbirinden ayrılmaktadırlar. Özellikle belli bir ürün için markaya duyulan duygusal ve psikolojik bağlılık marka sadakati olarak tanımlanır ancak marka bağılığı ise tüketicilerin satın almasını kolaylaştıran bir faktördür. Tercih edilen markada talep edilen ürünün olmaması, tüketicileri başka markalara yönlendirebilirken, marka sadakatinde bu durum gerçekleşmez (Warrington ve Shim, 2000, s. 762). Literatürde yer alan ve belirtilen bulgulardan yola çıkarak aşağıdaki hipotez kurgulanmıştır.

$H_{7}$ : Müsteri marka memnuniyetinin, satın alma niyeti üzerine olumlu ve anlamlı bir etkisi vardvr.

Müşteri marka memnuniyetinin öncülleri arasında sayılan marka imajı ve marka güveni ile sonuçları arasında sayılan satın alma ve marka bağılığının aralarındaki ilişkide marka memnuniyetinin aracılılık rolünü inceleyen literatürde yer alan ve belirtilen bulgulardan yola çıkarak aşağıdaki hipotezler kurgulanmışır (Aşkın ve İpek, 2016, s. 81; Aydın, 2017, s. 282; Kalyoncuoğlu, 2017, s. 390; Özbek vd., 2020, s. 655;).

$H_{8}$ : Marka imajinn, satın alma niyetine etkisinde müsteri marka memnuniyetinin aracı rolü vardir.

$H_{9}$ : Marka güveninin, marka bağhllğgna etkisinde müsteri marka memnuniyetinin aracı rolü vardır.

\section{Yöntem}

\section{Araştırma Amacı ve Modeli}

Çalışmada, genç cep telefonu kullanıcılarında marka güveni ve marka imajının müşteri marka memnuniyetine etkisi, müşteri marka memnuniyetinin ise marka bağlllğı, marka sadakati ve satın alma niyeti üzerindeki etkisinin tespiti amaçlanmıştır. Ayrıca araştırmada, marka güvenin marka bağlılığına etkisinde ve marka imajının satın alma niyetine etkisinde müşteri marka memnuniyetinin aracı rolünün tespiti de amaçlanmıştır. Araştırma modeli Şekil 1'de sunulmuştur. 


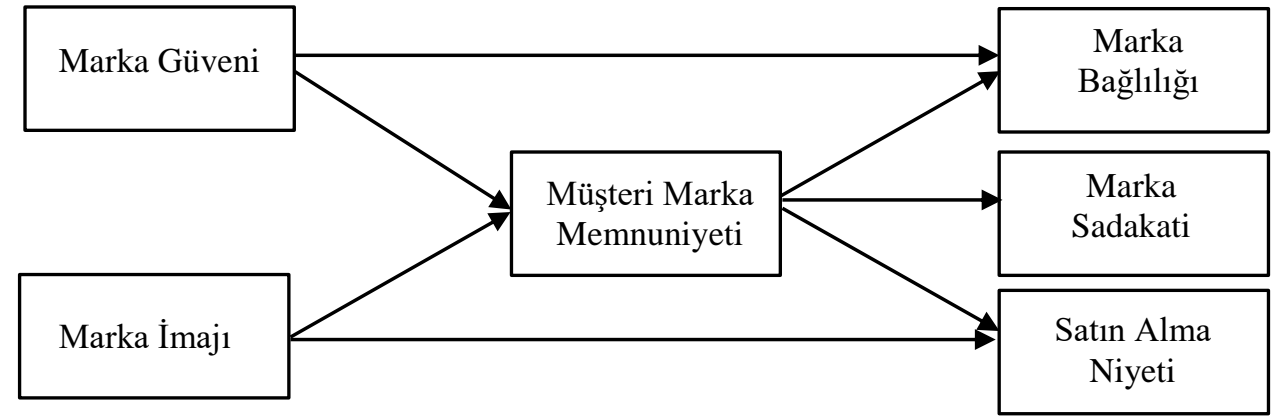

Şekil 1. Arasțtrma Modeli

Çalışmada modele bağlı olarak başta kavramsal çerçeve üzerinde durulmuş, ardından araştırma yöntemi ve metot belirlenmiştir. Araştırmada korelasyon ve regresyon analizleri uygulanmış ve araştırma amacına yönelik belirlenen 9 adet hipotez yapılan analizler sonucu incelenmiştir.

\section{Evren ve Örneklem}

Araştırma İstanbul/Kadıköy'de kolayda örneklem yöntemiyle seçilen 20-30 yaş grubu yetişkin gençlerden elde edilen verilerle yapılmıştır. Araştırmanın amaçları doğrultusunda hazırlanan anketler araştırmacılar tarafindan katılımcılara yüz yüze uygulanmıştır. Toplam 1000 anket hazırlanmış ve 848 ankette geri dönüş sağlanmıştır. Elde edilen anketler incelendiğinde eksik ve hatalı doldurulan 36 anket, cep telefonu kullanmadığını belirten 17 anket ve 20-30 yaş grubunun dışında kalan 46 katılımcının anketleri araştırma kapsamı dışına alınmıştır. Analizler 749 geçerli anketten elde edilen verilere dayanmaktadır.

\section{Veri Toplama Araçları}

Araştırmanın amacı doğrultusunda oluşturulan anket formu 6 bölümden oluşmaktadır. Ölçekte yer alan ifadeler 1'den (Kesinlikle Katılmıyorum) 5'e kadar (Kesinlikle Katıllyorum) derecelendirilmiş 5'li Likert ölçeğidir. Anket formunda toplam 33 ifade bulunmaktadır. 33 ifadenin 8 tanesi katılımcıların demografik özelliklerini tespit etmeye yöneliktir.

Örneklem grubuna anket uygulaması yapılmadan önce, araştırmanın amacına yönelik oluşturulan anket 40 kişilik bir pilot gruba uygulanmıştır. Anlaşılmayan veya tereddüt yaşanan sorular yeniden düzenlenmiş ve aynı gruba tekrardan uygulanmıştır. Pilot uygulamanın anket sonuçları IBM SPSS 23 programı ile analiz edilerek güvenilirliği test edilmiştir. Cronbach alfa değeri 0,84 olarak ölçülen anket, yeterli güvenilirlik seviyesinde bulunarak örneklem üzerinde uygulanmıştır.

Müsteri Marka Memnuniyeti: Lam, Shankar, Erramilli ve Murthy, (2004) tarafindan geliştirilen ölçek kullanılmıştır. Ölçekte müşteri marka memnuniyetine yönelik olarak 5'li Likert sisteminde hazırlanmış 5 ifade bulunmaktadır. Ölçeğin yapılan araştırmada Cronbach alfa güvenilirlik katsayısı 0,824 olarak ölçülmüştür.

Marka Imajı: Marka imajının belirlenmesine yönelik olarak Aydın ve Özer (2005) tarafından geliştirilen ölçek kullanılmıştır. 4 ifadeden oluşan ölçek 5’li Likert sisteminde hazırlanmıştır. Ölçeğin Cronbach alfa güvenilirlik katsayısı 0,859 olarak ölçülmüştür.

Marka Güveni: İlgili yazındaki ölçekler incelenerek, Şimşek ve Noyan (2009) tarafindan geliştirilen ve Türkiye'de cep telefonu kullanımında marka güvenini ölçmeye yönelik olarak uygulanan 5'li Likert sisteminde hazırlanmış üç ifadeli ölçek kullanılmıştır. Ölçeğin yapılan araştırmada Cronbach alfa güvenilirlik katsayısı 0,839 olarak ölçülmüştür.

Marka Bağhllğg: Marka bağllığının ölçülmesine yönelik olarak, Ayas'in (2012) yaptığ1 araştırmada kullanılan ve altı ifadeden oluşan ölçek kullanılmışıtır. 5'li Likert sisteminde hazırlanan ölçeğe ait örnek sorular; "Yeni bir cep telefonu alacak olsam X markası ilk tercihim olacaktır", "Başka bir marka cep telefonu X ile aynı özelliklere sahip olsa bile X markasını tercih ederim" ve "Diğer bir marka cep telefonunun herhangi bir farkı olmasa da X markasını tavsiye ederim" şeklindedir. Ölçeğin Cronbach alfa güvenilirlik katsay1s1 0,893 olarak ölçülmüştür.

Marka Sadakati ve Satın Alma Niyeti: Nguyen ve Leblanc (2001) çalışmasından faydalanılarak Marangoz (2007) tarafından Türkiye'de cep telefonu satın alımına yönelik olarak yapılan araştırmada kullanılan ve üç ifadeden oluşan ölçek kullanılmıştır. 5'li Likert sisteminde hazırlanan ölçek "Yeni bir cep telefonu alsaydım 
yine X markasını tercih ederdim”, "Bu cep telefonu markasını sürekli olarak satın alacağım” ve "Bu marka cep telefonunu kullanmaya devam edeceğim" ifadelerinden oluşmaktadır. Marka sadakati ölçeğin Cronbach alfa güvenilirlik katsayısı 0,911 , satın alma niyeti ölçeğinin ise 0,871 olarak ölçülmüsstür.

Araştırma kapsamın alınan değişkenlerin Cronbach alfa güvenilirlik katsayıları literatürde önerilen ve alt eşik değeri olan 0,7 ve üzerindedir (Sürücü ve Maslakç1, 2020). Elde edilen değerler ölçeklerinin güvenilir olduğunu göstermektedir.

\section{Bulgular}

Araştırmada SPSS ve AMOS programı yardımıyla analizler yapılmıştır. Öncelikle tanımlayıcı istatiksel analizler, daha sonra ölçeklerin geçerlik ve güvenirliklerin tespitine yönelik analizler yapılmıştır. Değişkenlerin birbiri ile ilişkilerini tespit etmeye yönelik korelasyon analizi, etkinin tespitine yönelik ise regresyon analizleri yapılmıştır. Araştırma modelindeki aracılık etkisinin tespit edilmesine yönelik olarak ise Hayes (2017) tarafından geliştirilen PROCESS Macro istatistik programı kullanılmıştır.

\section{Demografik Bulgular}

Araştırma kapsamında katılımcıların demografik özellikleri Tablo 1'de sunulmuştur. Tablo 1 incelendiğinde katılımcıların çoğunluğunun erkek (\% 57), 24-27 yaş aralığında (\%44) ve 2000 TL ve az gelire sahip olduğu görülmektedir. Ayrıca katılımcıların büyük çoğunluğu lisans (\% 60) eğitimine sahiptir.

Tablo 1. Katulmmolarm Demografik Özellikleri

\begin{tabular}{llcc}
\hline & Değ̈işken & Frekans & \% \\
\hline \multirow{2}{*}{ Cinsiyet } & Kadın & 319 & 43 \\
& Erkek & 430 & 57 \\
\hline \multirow{3}{*}{ Yaş } & $20-23$ & 251 & 33 \\
& $24-27$ & 327 & 44 \\
\hline \multirow{3}{*}{ Ĕ̈itim Durumu } & $28-30$ & 171 & 23 \\
\hline \multirow{4}{*}{ Gelir Durumu } & İlköğretim & 255 & 34 \\
& Lisans & 453 & 60 \\
& Lisansüstü & 41 & 6 \\
\hline & 2000 TL ve az & 400 & 53 \\
& 2000-3000 & 219 & 29 \\
& $3000-4000$ & 90 & 12 \\
\hline
\end{tabular}

\section{Geçerlik ve Güvenirlik Analizleri}

Araştırma hipotezlerinin test edilmesinden önce araştırma kapsamına alınan değişkenlerin geçerlik ve güvenilirliği kontrol edilmiştir. Yapılan analizler neticesinde elde edilen değerler Tablo 2'de sunulmuştur. Araştırma kapsamına alınan değişkenlerin yapısal geçerliğini test etmek ve alt boyutlarının tespit edilmesine yönelik yapılan keşfedici faktör analizinde (KFA) varimaks döndürme ekseninde temel bileşenler metodu uygulanmıştır. Yapılan KFA analizinde Kaiser Meyer Olkin (KMO) değerlerinin 0,7'den büyük olmas1, örneklem büyüklügünün faktör analizi için yeterli olduğunu, Barlett küresellik testi sonucunun anlamlı olması ise faktörler ile faktörlerin oluşturduğu yap1 arasında bir uyumun (korelasyon) olduğunu göstermektedir (Tabachnick, Fidell ve Ullman, 2007). Araştırma modelinin uyum indekslerinin tespit edilmesine yönelik olarak Doğrulayıcı Faktör Analizi (DFA) yapılmıştır. DFA analiz sonuçları Tablo 2'de sunulmuştur.

Tablo 2. Doğrulayıc Faktör Analiz. Sonuclar

\begin{tabular}{lcccccc}
\hline & CMIN/DF & GFI & NFI & TLI & CFI & RMSEA \\
\hline Tek Faktörlü Model & 6,254 & 0,652 & 0,740 & 0,658 & 0,788 & 0,066 \\
Üç Faktörlü Model & 5,251 & 0,711 & 0,688 & 0,702 & 0,625 & 0,421 \\
Beş Faktörlü Model & 3,269 & 0,844 & 0,856 & 0,799 & 0,812 & 0,084 \\
Araştırma modeli (6 Faktör) & 2,259 & 0,892 & 0,901 & 0,877 & 0,921 & 0,051 \\
\hline MMM: Müsteri Marka Memnuniveti, MG: Marka Güveni, MI: Marka İmaj, MB: Mark.a Bağhluğg, MS: Marka Sadakati, SAN: Satın
\end{tabular}

Yapılan DFA analizinde farklı modellerin uyum indeksleri incelenmiş ve araştırma modelinin iyi uyum indekslerine sahip olduğu tespit edilmiştir $(\mathrm{CMIN} / \mathrm{df}=2,259 ; \mathrm{p}<0,001$; GFI $=0,892$, NFI $=0,901$, TLI $=0,877, \mathrm{CFI}=0,921, \mathrm{RMSEA}=0,051)$. 
Ölçeklerinin geçerlik ve güvenirliklerinin tespitine yönelik yapılan analiz sonuçları Tablo 3'de sunulmuştur.

Tablo 3. Gecerlik ve Güvenirlik Sonuclar

\begin{tabular}{|c|c|c|c|c|c|}
\hline & Ifade & Faktör Yükleri & $A V E$ & $C R$ & Cronbach \\
\hline \multirow{5}{*}{$\begin{array}{l}\text { Müssteri Marka } \\
\text { Memnuniyeti }\end{array}$} & MMM 1 & 0,742 & 0,510 & 0,838 & 0,824 \\
\hline & MMM 2 & 0,730 & & & \\
\hline & MMM3 & 0,701 & & & \\
\hline & MMM 4 & 0,695 & & & \\
\hline & MMM 5 & 0,702 & & & \\
\hline \multirow{3}{*}{ Marka Güveni } & MG 1 & 0,510 & 0,626 & 0,827 & 0,839 \\
\hline & MG 2 & 0,921 & & & \\
\hline & MG 3 & 0,878 & & & \\
\hline \multirow{4}{*}{ Marka İmaj1 } & Mİ 1 & 0,618 & 0,543 & 0,824 & 0,859 \\
\hline & Mİ 2 & 0,821 & & & \\
\hline & Mİ 3 & 0,679 & & & \\
\hline & Mİ 4 & 0,810 & & & \\
\hline \multirow{6}{*}{ Marka Bağlllı̆̆1 } & MB 1 & 0,674 & 0,501 & 0,857 & 0,893 \\
\hline & MB 2 & 0,755 & & & \\
\hline & MB 3 & 0,655 & & & \\
\hline & MB 4 & 0,716 & & & \\
\hline & MB 5 & 0,712 & & & \\
\hline & MB 6 & 0,729 & & & \\
\hline \multirow{5}{*}{ Marka Sadakati } & MS 1 & 0,601 & 0,502 & 0,892 & 0,911 \\
\hline & MS 2 & 0,737 & & & \\
\hline & MS 3 & 0,711 & & & \\
\hline & MS 4 & 0,687 & & & \\
\hline & MS 5 & 0,777 & & & \\
\hline \multirow{3}{*}{ Satın Alma Niyeti } & SAN 1 & 0,716 & 0,639 & 0,840 & 0,871 \\
\hline & SAN 2 & 0,851 & & & \\
\hline & SAN 3 & 0,825 & & & \\
\hline
\end{tabular}

Ölçeklere ait ortalama açıllanan varyans değerleri (AVE) 0,501 ve üzerindedir. Bu değerler yakınsak geçerliliğin sağlanabilmesi için kritik değer olan 0,5' in üzerindedir (Hair vd., 2007). AVE değerinin 0,5' in üzerinde olması ve aynı zamanda birleşik güvenirlik (CR) değerlerinin AVE değerlerinden yüksek olması, ölçeklerin yakınsak geçerliliğini olduğunu göstermektedir (Fornell ve Larcker, 1981). Yakınsak geçerlilik ölçekte yer alan ifadelerin temsil ettikleri alt boyutları yeterli oranda açıkladığını ve birbirleri ile tutarlı olduğunu göstermektedir. Ayrıca ölçeklere ait ifadelerin faktör yükleri 0,510 ile 0,902 arasında olduğu görülmektedir. Bu değerler ölçekte yer alan ifadelerin ölçeğin yapısına uygun olduğunu göstermektedir (Hair vd. 2007).

Ölçeklerin Croanbach alfa değerleri ve bileşik güvenirlik değerleri 0,7 ve üzerindedir. Elde edilen değerler ölçeklerin iç tutarlllığının olduğunu göstermektedir. Araştırma kapsamına alınan değişkenlerin birbirleri ile olan korelasyon, ortalama ve standart sapma değerleri Tablo 4'de sunulmuştur.

Tablo 4. Ortalama, Standart Sapma ve Korelasyonlar

\begin{tabular}{|c|c|c|c|c|c|c|c|c|}
\hline & Art. Ort. & Std. Sp. & 1 & 2 & 3 & 4 & 5 & 6 \\
\hline Müşteri Marka Memnuniyeti & 3,82 & 1,12 & 1 & & & & & \\
\hline Marka Güveni & 3,88 & 0,96 & $0,480 * *$ & 1 & & & & \\
\hline Marka İmaj1 & 3,64 & 1,08 & $0,611 * *$ & $0,451 * *$ & 1 & & & \\
\hline Marka Bağlılığ1 & 3,62 & 1,04 & $0,581 * *$ & $0,601 * *$ & $0,560 * *$ & 1 & & \\
\hline Marka Sadakati & 3,65 & 1,12 & $0,680 * *$ & $0,587 * *$ & $0,657 * *$ & $0,759 * *$ & 1 & \\
\hline Satın Alma Niyeti & 3,64 & 1,14 & $0,514 * *$ & $0,582 * *$ & $0,481 * *$ & $0,806^{* *}$ & $0,725^{* *}$ & 1 \\
\hline Çarp1klık (Skewness) & - & - & $-0,966$ & $-0,846$ & $-0,693$ & $-0,499$ & $-0,634$ & $-0,578$ \\
\hline Basıkl1k (Kurtosis) & - & - & 0,255 & 0,435 & $-0,232$ & $-0,589$ & $-0,458$ & $-0,556$ \\
\hline
\end{tabular}

** $\mathrm{p}<0,05$

Verilerin dağılımı istatiksel analizler tercihinde önemlidir (Sürücü ve Maslakçı, 2020). Bu nedenle korelasyon analizinden önce verilerin dağılımı tespit edilmiştir. Hair vd (2007) çarpıklık ve basıklık değerlerinin -1.5 ile +1.5 arasında olması durumunda verilerin normal dağılım gösterdiğini belirtmektedir. Yapılan analizler neticesinde (Tablo 4) çarpıklık ve basıklık değerlerinin önerilen sınırlar dâhilinde olduğu 
ve verilerin normal dağılıma sahip olduğunu tespit edilmiştir. Bu nedenle korelasyon analizinde Pearson korelasyon katsayıları dikkate alınmıştır.

Değişkenler arasındaki ilişkinin yönünü ve kuvvetini gösteren Tablo 4 incelendiğinde, değişkenler arasında korelasyonların $r=0,480$ ile $r=0,806$ arasında olduğu görülmektedir. Elde edilen değerler araştırma kapsamına alınan değişkenlerin birbiri ile ilişkili olduğunu ve araştırma hipotezlerinin test edilebileceğini göstermektedir.

\section{Araştırma hipotezlerinin testi}

Müşteri marka memnuniyetinin, öncülleri ve sonuçlarının belirlenmesine yönelik olarak; marka güveni, marka imajı, marka bağlılığı, marka sadakati ve satın alma niyeti içeren kavramsal modelin test edilmesi için regresyon analizleri yapılmışır. İki aşamada yapılan regresyon analizinin ilk aşamasında demografik değişkenler kontrol altına alınmış, ikinci aşamada ise modele bağımsız değişken dâhil edilmiştir. Yapılan regresyon analiz sonuçları Tablo 5'de sunulmuştur.

Tablo 5. Regresyon Sonuclarn

\begin{tabular}{|c|c|c|c|c|c|}
\hline & $\beta$ & $S H$ & $t$ & $p$ & $\boldsymbol{R}^{2}$ \\
\hline Marka Güveni ---> Marka Bağl1lı̆̆1 & 0,650 & 0,032 & 20,546 & 0,000 & 0,361 \\
\hline Marka Güveni ---> Müşteri Marka Memnuniyeti & 0,558 & 0,037 & 14,945 & 0,000 & 0,230 \\
\hline Marka İmaj1 ---> Satın Alma Niyeti & 0,505 & 0,034 & 14,977 & 0,000 & 0,230 \\
\hline Marka İmajı ---> Müşteri Memnuniyeti & 0,684 & 0,029 & 24,098 & 0,000 & 0,437 \\
\hline Müşteri Marka Memnuniyeti ---> Marka Bağlılığ1 & 0,540 & 0,028 & 19,488 & 0,000 & 0,337 \\
\hline Müşteri Marka Memnuniyeti ---> Marka Sadakati & 0,679 & 0,027 & 25,324 & 0,000 & 0,462 \\
\hline Müşteri Marka Memnuniyeti ---> Satın Alma Niyeti & 0,522 & 0,032 & 16,354 & 0,000 & 0,264 \\
\hline
\end{tabular}

Regresyon sonuçları; marka güveninin, marka bağlllı̆̆1 $(\beta=0,650, p=0,001)$ ve müşteri marka memnuniyeti $(\beta=0,558, p=0,001)$ üzerinde anlamlı ve olumlu yönlü bir etkisinin olduğunu, marka imajinın, müşteri marka memnuniyeti $(\beta=0,505, p=0,001)$ ve satın alma niyeti $(\beta=0,684, p=0,001)$ üzerinde anlamlı ve olumlu yönlü bir etkisinin olduğunu göstermektedir. Bu bulgular ilave olarak müşteri marka memnuniyeti; marka bağlllı̆ı $(\beta=0,540, \mathrm{p}=0,001)$, marka sadakati $(\beta=0,679, \mathrm{p}=0,001)$ ve satın alma niyeti $(\beta=0,522, \mathrm{p}=0,001)$ üzerinde anlamlı ve olumlu yönlü bir etkisinin olduğu tespit edilmiştir. Elde edilen bulgular 1şı̆̆ında Hipotez 1, 2, 3, 4, 5, 6, 7 kabul edilmiştir.

Araştırma modelindeki aracllık etkisinin tespit edilmesine yönelik olarak Hayes (2017) tarafindan geliştirilen PROCESS Macro istatistik programı kullanılmıştır. Marka imajının satın alma niyetine etkisinde müşteri marka memnuniyetinin aracı rolünün tespitine yönelik yapılan analizlerin sonuçları Tablo 6'da sunulmuştur.

Tablo 6. Marka İmajimn Satn Alma Niyetine Etkisinde Müsteri Marka Memnuniyetinin Aracı Rolï

\begin{tabular}{|c|c|c|c|c|}
\hline & $\beta$ & $S E$ & $L L C I$ & $U L C I$ \\
\hline Marka İmaj1 ---> Satın Alma Niyeti & 0,264 & 0,430 & 0,179 & 0,348 \\
\hline Marka İmaj1 ---> Müşsteri Marka Memnuniyeti & 0,684 & 0,029 & 0,629 & 0,740 \\
\hline Müşteri Marka Memnuniyeti ---> Satın Alma Niyeti & 0,353 & 0,042 & 0,272 & 0,435 \\
\hline (Dolaylı etki) Mİ ---> MM ---> SAN & 0,242 & 0,354 & 0,172 & 0,314 \\
\hline
\end{tabular}

MI: Marka İmajı, MM: Müşteri Marka Memnuniyeti, SAN: Satın Alma Niyeti

Regresyon analizi sonucunda elde edilen sonuçlara göre; marka imajı, satın alma niyetini $(\beta=0,264$, $95 \% \mathrm{CI}=[0,179,0,348], \mathrm{t}=6,1296, \mathrm{p}<0,05)$ ve müşteri marka memnuniyetini $(\beta=0,684,95 \% \mathrm{CI}=[0,629$, $0,740], \mathrm{t}=24,096, \mathrm{p}<0,05)$ anlamlı ve olumlu yönde etkilemektedir. Ayrıca, müşteri marka memnuniyeti de satın alma niyetini anlamlı ve olumlu yönde etkilemektedir $(\beta=0,353,95 \% \mathrm{CI}=[0,272,0,435], \mathrm{t}=8,512$, $\mathrm{p}<0,05)$. Müşteri marka memnuniyetinin aracı rolüne yönelik olarak dolaylı etkinin $(\beta=0,242, \mathrm{SE}=0,354$, $95 \%$ BCA CI $=[0,172,0,314])$, alt (LLCI) ve üst (ULCI) güven aralığı hiçbir durumda sıfır (0) içermediği için anlamlı olduğu (Hayes, 2017) görülmektedir. Bu bulgu ışığında hipotez 8 kabul edilmiştir. Aracı etkinin tespitine yönelik olarak VAF değeri hesaplanmıştır. VAF değeri dolaylı etki/toplam etki * 100 formülü ile elde edilmektedir. Hair vd. (2007), VAF değerinin \% 80 ve üzerinde olması durumunda tam aracilık, \% 20- \% 80 arasında olması durumda ise kısmi aracilığın olduğunu belirtmektedir. Yapilan analizler VAF değerinin \% 82 olduğunu ve müşteri marka memnuniyetinin tam aracıllk rolü olduğunu göstermektedir. 
Marka güveninin marka bağlllı̆̆ına etkisinde müşteri marka memnuniyetinin aracı rolünün tespitine yönelik yapılan analizlerin sonuçları Tablo 7'de sunulmuştur.

Tablo 7. Marka Güveninin Marka Bağhlluğgna Etkisinde Müsteri Marka Memnuniyetinin Aracı Rolü

\begin{tabular}{|c|c|c|c|c|}
\hline & $\beta$ & $S E$ & $L L C I$ & $U L C I$ \\
\hline Marka Güveni ---> Marka Bağlllığ1 & 0,452 & 0,328 & 0,388 & 0,517 \\
\hline Marka Güveni ---> Müssteri Memnuniyeti & 0,558 & 0,037 & 0,486 & 0,631 \\
\hline Müşteri Memnuniyeti ---> Marka Bağllliğ1 & 0,353 & 0,028 & 0,298 & 0,408 \\
\hline (Dolaylı etki) MG ---> MM ---> MB & 0,197 & 0,023 & 0,156 & 0,242 \\
\hline
\end{tabular}

MG: Marka Güveni, MM: Müşteri Memnuniyeti, MB: Marka Bağhllı̆̆ı

Regresyon analizi sonucunda elde edilen sonuçlara göre; marka güveni, marka bağlllı̆̆ını $\quad(\beta=0,452$, $95 \% \mathrm{CI}=[0,388,0,517], \mathrm{t}=13,810, \mathrm{p}<0,05)$ ve müşteri marka memnuniyetini $(\beta=0,558,95 \% \mathrm{CI}=[0,486$, $0,631], \mathrm{t}=14,944, \mathrm{p}<0,05)$ anlamlı ve olumlu yönde etkilemektedir. Ayrıca, müssteri marka memnuniyeti de marka bağlıllğını anlamlı ve olumlu yönde etkilemektedir $(\beta=0,353,95 \% \mathrm{CI}=[0,298,0,408], \mathrm{t}=12,522$, $\mathrm{p}<0,05)$. Bu bulgular doğrultusunda müşteri marka memnuniyetinin aracı rolüne yönelik olarak dolaylı etkinin $(\beta=0,197, \mathrm{SE}=0,023,95 \% \mathrm{BCA} \mathrm{CI}=[0,156,0,242])$, alt (LLCI) ve üst (ULCI) güven aralığı hiçbir durumda sıfır (0) içermediği için anlamlı olduğu (Hayes, 2017) görülmektedir. Bu bulgu sşığında hipotez 9 kabul edilmiştir. Yapılan analizler VAF değerinin \% 51 olduğunu ve müşteri marka memnuniyetinin kısmi aracilık rolü olduğunu göstermektedir.

\section{Tartışma, Sonuç ve Öneriler}

Bu çalışmada genç yetişkinlerin cep telefonu kullanımında marka güveni, marka imajı ve müşteri marka memnuniyetinin, marka bağlllı̆ı, marka sadakati ve satın alma niyetine etkisini tespit etmenin yanı sıra, müşteri marka memnuniyetinin marka bağlllı̆ı, marka sadakati ve satın alma niyeti üzerindeki aracılık rolü ortaya konmaya çalışılmıştır.

Çalışma kapsamında belirlenen hipotezlerin test edilmesi sonucunda, araştırma modeline bağlı olarak belirlenen dokuz hipotezin de kabul edildiği görülmüştür. Birinci ve ikinci hipotezler ve analiz sonuçları incelendiğinde, müşterilerin marka güveninin marka bağlllı̆̆ ve marka memnuniyeti üzerine anlamlı ve olumlu bir etkisi olduğu sonucuna ulaşılmışır. Elde edilen bu bulgu, genç cep telefonu kullanıcılarının, daha pahalı olsa bile güvendiği ve ihtiyaçlarını karşıladığını düşündükleri cep telefonu markalarını diğer markalara tercih edeceklerini ve bir sonraki alşsverişlerinde de aynı markayı tercih edeceklerini göstermektedir. Ayrıca genç cep telefonu kullanıcılarının, marka değeri olduğunu düşündükleri cep telefonu markasından memnuniyet duyduklarını ve bu değerin güven ile pekiştirilmesi sonucu daha sonraki zamanlarda da aynı cep telefonu markasını tercih edecekleri görülmüștür. Marka güveni ile marka bağlllı̆̆1 ve marka memnuniyeti ilişkisini araştıran çalışmalarda, güven ile bağlllık ve memnuniyet arasında anlaml, olumlu ve doğru bir orantı olduğu sonucuna ulaşılmıştır. Ayrıca bu sonuçlar literatürdeki çalışmalar ile desteklemektedir (Albert ve Merunka, 2013, s. 265; Atılgan, Aksoy ve Akınc1, 2005, s.73; Ayas, 2012, s. 275; Bernal, 2014, s. 44; Chaudhuri ve Holbrook, 2001, s. 90; Doğru ve Koçer, 2016, 144; Turhan, 2009, s. 183).

Üçüncü ve dördüncü hipotezler ve analiz sonuçları incelendiğinde, marka imajının satın alma niyeti ve marka memnuniyeti üzerine anlamlı ve olumlu bir etkisi olduğu sonucuna ulaşılmıştır. Elde edilen bu bulgu, genç cep telefonu kullanıcılarının, cep telefonu markalarının imajlarını ve bu markalardan duydukları memnuniyeti birlikte değerlendirdiklerinde, yine ayn1 markayı tercih edeceklerini göstermektedir. Ayrıca marka imajının, müşteriler üzerinde cesur tavır sergileme ve kendilerinden emin olma konularında da olumlu etkileri olduğu görülmüş̧ür. Marka imajı ile marka satın alma ve müşterilerin marka memnuniyeti ilişkisini araştıran çalışmalarda, imaj ile satın alma ve memnuniyet arasında anlaml, olumlu ve doğru bir orantı olduğu sonucuna ulaşılmıştır. Ayrıca bu bulgular literatürdeki çalışmalar ile desteklemektedir (Atılgan ve Yükselen, 2018, s. 38; Demir, 2009, s. 76; Değirmenci ve Durmaz, 2020, s. 272; Macdonald ve Sharp, 2000, s. 8; Sönmez, 2010, s. 69; Zeren ve Gökdağlı, 2017, s. 93).

Müşteri marka memnuniyetinin, marka bağlılığı, satın alma niyeti ve marka sadakati üzerine etkisinin incelendiği hipotezlerde, bu faktörler üzerinde anlamlı ve olumlu bir etkisinin olduğu tespit edilmiştir. Ayrıca müşteri marka memnuniyetinin öncüllerini oluşturan faktörler ile sonuçları olarak değerlendirilen faktörler arasında aracılık rolünün olduğu anlaşılmıştır. Müşteri marka memnuniyetinin öncüllerini oluşturan faktörler ve müşteri marka memnuniyeti ilişkilerini araştıran çalışmalar incelendiğinde, 
literatürdeki çalışmaların da bulguları desteklediği görülmektedir (Andreani, Taniaji ve Puspitasari, 2012, s. 68; Aydın, 2016, s. 131; Hussain, 2016, s. 252; Uludağ, Faiz ve Çat1, 2018, s. 589; Yetkil, 2017, s. 44).

Bu çalışmanın, müşteri marka memnuniyetinin öncüllerinin (marka güveni ve marka imaji), marka bağlılığ1 ve satın alma davranışı üzerindeki etkileri ve müşteri marka memnuniyetinin öncüller ile marka bağlılığı ve satın alma niyeti arasında aracılık rolü ile ilgili konularda, marka yaratmada araştırmacılara ve uygulayıcılara fikir verilmesi beklenmektedir. Ayrıca firmaların marka bağlılığı ve sadakati yaratmada marka imajının yanı sıra, güven ve fonksiyonellik gibi hususları da göz önünde bulundurmaları gerekmektedir. Çalışma, literatüre katkı sağlamanın yanı sıra marka yaratma ya da geliştirme konularında uygulayıcı olarak rol alan/alacak olan işletmeler için de öneriler sunmaktadır. İşletmeler, ürün/hizmetlerinin fonksiyonel ya da fiziksel faydalarının yanı sıra soyut faydalara da odaklanmaları gerektiğini, müssterilerde oluşan marka algısının hem işletmenin satış ve gelirlerinde hem de pazardaki yeri için önemli olduğunu değerlendirmeleri gerekmektedir.

İşletmelerin müşterilerinin gözünde iyi bir yer edilebilmesinin yollarından birisi de güçlü bir marka imajı yaratılmasıdır. İşletmelerin bunu başarabilmek için müşterilerine marka aşinalığı sağlaması, marka bilincinden sonra marka güveni ve müşteri memnuniyeti ile markalarına bağlı ve sadık müşteriler elde etme yoluna gitmeleri gerekmektedir. Bu nedenle işletmeler pazarlama stratejilerinde öncelikle marka bilincini ve aşinalığını artıran stratejilere yer vermeli ve marka imajlarında yaptıkları iyileştirmelerle iyi bir memnuniyet, güven ve bağlllık düzeyi geliştirmelilerdir.

Çalışmanın ileride yapılacak çalışmalara yol gösterici olabileceği beklenmektedir. Çalışmanın örneklemi genç tüketiciler, araştırma konusu ise cep telefonu markaları ve kullanımı ile kısıtlanmıştır. $\mathrm{Bu}$ sebeple toplanan veriler ile genç cep telefonu kullanıcıları ve cep telefonu sektörüne özgü bir model oluşturulmuştur. İleride yapılacak çalışmaların, farklı sektör ve tüketici grupları üzerinde uygulanmasının konu ile ilgili daha ayrıntılı değerlendirme yapma imkânı sağlayacağı değerlendirilmektedir.

\section{Etik Beyan}

"Cep Telefonu Sektöründe Müssteri Marka Memnuniyetinin Öncülleri ve Sonucları" başlıklı çalışmanın yazım sürecinde bilimsel kurallara, etik ve alıntı kurallarına uyulmuş; toplanan veriler üzerinde herhangi bir tahrifat yapilmamış ve bu çalışma herhangi başka bir akademik yayın ortamına değerlendirme için gönderilmemiştir. Bu araştırmanın verileri 01.01.2020 tarihinden önce toplandığ1 ve makalenin süreci 2020 yllında başladığından etik kurul kararı zorunluluğu taşımamaktadır.

\section{Kaynakça}

Aaker, D. A. (2009). Managing Brand Equity. New York: The Free Press.

Albert, N. ve Merunka, D. (2013). The role of brand in consumer-brand relationships. Journal of Consumer Marketing. 30(3), 258-266.

Andreani, F., Taniaji, T.L. ve Puspitasari, R.N.M. (2012). The impact of brand image towards loyalty with satisfaction as a mediator in Mcdonald's. Jurnal Manajemen Dan Kewirausabaan, 14(1), 64-71.

Aşkın, N. ve İpek, İ. (2016). Marka aşkının marka deneyimi ile marka sadakati arasındaki ilişkiye araclıtk etkisi. Ege Akademik Bakıs Dergisi, 16(1), 79-94.

Atılgan, F. (2017). Marke yönetimi, Nobel Akademik Yayıncılık Eğitim Danışmanlık Ltd.Şti. İstanbul.

Atılgan, E., Aksoy, S. ve Akınc1, S. (2005). Determinants of the brand equity: A verification approach in the beverage industry in Turkey. Marketing Intelligence \& Planning, 23(3), 69-88.

Atılgan, F. ve Yükselen, C. (2018). Marka tutumu ile imajının marka değeri ve güveni yaratılmasındaki rolü, tüketicilerin satın alma niyeti üzerindeki etkileri. Beykent Üniversitesi Sosyal Bilimler Dergisi, 11(1), 35-53.

Ayas, N. (2012). Marka değeri algılamalarının tüketici satın alma davranışı üzerine etkisi. Girrșimcilik ve Kalkinma Dergisi, 7(1), 163-183.

Aydın, H. (2016). Marka aşkının değerlendirilmesi: Beyaz eşya kullanıcıları üzerine bir araş̧ırma. Tüketici ve Tüketim Arastrmalar Dergisi, 8(2), 125-149.

Aydın, H. (2017). Marka güveni, farkındalığı ve benlik imaj uyumunun marka bağlllığına etkisinde marka aşkının arac1lik rolü. Ege Academic Review, 17(2), 281-293.

Aydın, S. ve Özer, G. (2005). The analysis of antecedents of customer loyalty in the Turkish mobile telecommication market. European Journal of Marketing, 39(7/8). 910-917.

Blythe, J. (2001). Pazarlama ilkeleri, Bilim Teknik Yayınevi.

Bernal, C. V. K. (2014). Lovemarks: The emotional attachment of loving a brand (Doktora Tezi). Colegio de Estudios Superiopes de Administion.

Bostan, S., Acuner, T. ve Yilmaz, G. (2005). Hastane işletmelerinde müststeri (hasta) beklentileri arasstrması. Sağllk ve Hastane Yönetimi 2. Ulusal Kongresi, Bildiriler Kitabı. 
Carroll, B. A. ve Ahuvia, A. C. (2006). Some antecedents and outcomes of brandlove. Marketing Letters, 17(2), 79-89.

Chaudhuri, A. ve Holbrook, M.B. (2001). The chain of effects from brand trust and brand affect to brand performance: The role of brand loyalty. Journal of Marketing, 65(2), 81-93.

Değirmenci, B. ve Durmaz, Y. (2020). Tüketicilerin marka memnuniyeti marka bağımlılı̆̆1 ilişkisinde cinsiyet ve gelirin düzenleyici rolünün incelenmesi. Adiyaman Üniversitesi Sosyal Bilimler Enstitïiü Dergisi, 13(34), 266-298.

Demir, M. Ö. (2009). Tüketici imajinın ve marka imajı uyumunun marka sadakati üzerindeki etkisi (Doktora Tezi). Akdeniz Üniversitesi, Sosyal Bilimler Enstitüsü, Antalya.

Devrani, T. K. (2009). Marka sadakati öncülleri: Çalışan kadınların kozmetik ürün tüketimi üzerine bir çalışma, Süleyman Demirel Üniversitesi İktisadi İdari Bilimler Fakültesi Dergisi, 14(3), 407-421.

Doğru, S. ve Koçer, S. (2016). GSM operatörü kullanıcılarının marka sadakati üzerine bir inceleme. Global Media Journal TR Edition. 6(12), 131-171.

Doney, P.M. ve Cannon, J.P. (1997). An examination of the nature of trust in buyer-seller relationships. Journal of Marketing, 61, 35-51.

Düzgün, Z. (2015). Tüketicilerin pazarlama karması algisı ve satın alma tarz̨larnnn müsteri memnuniyeti, markaya duyulan güven ve tüketici temelli marka değeri üzerindeki etkileri (Yüksek Lisans Tezi). Doğuş Üniversitesi Sosyal Bilimler Enstitüsü.

Erdil, T. S. ve Uzun, Y. (2010). Marka olmak (2. Baskı). İstanbul: Beta Basım Yayım Dağıtım.

Eren, S. S. ve Erge, A. (2012). Marka güveni, marka memnuniyeti ve müşteri değerinin tüketicilerin marka sadakati üzerine etkisi. Yaşar Üniversitesi Dergisi, 26(7), 4455-4482.

Fornell, C. ve Larcker, D. F. (1981), Evaluating structural equation models with unobservable variables and measurement error. Journal of Marketing Research, 18(1), 39-50.

Hair, J. F., Black, W. C., Babin, B. J., Anderson, R. E. ve Tatham, R. L. (2007). Multivariate data analysis, Upper Saddle River, NJ: Prentice Hall, 5(3), 87-135.

Hayes, A. F. (2017). Introduction to mediation, moderation and conditional process analysis: a regression-based approach. Guilford Publications.

Hussain, R, (2016). The mediating role of customer satisfaction: Evidence from the airline industry, Asia Pacific Journal of Marketing and Logistics, 28(2), 234-255.

Kalyoncuoğlu, S. (2017). Markaya duyulan güven ile marka sadakati ilişkisinde marka aşkının aracilık rolü: Starbucks markası üzerine bir araştırma. The Mediating Role of Brand Love in the Journal of Tourism and Gastronomy Studies, 5(4), 383-402.

Kayalı, C. A., Yereli A., Soysal M. ve Terim, B. (2004). Marka değerinin firmaların piyasa değeri ve finansal performansları üzerindeki etkileri. 8. Ulusal Finans Sempozyumu, 27-28 Ekim, İstanbul, 180-195.

Kavas, A. (2004). Marka değeri yaratma. PI Pazarlama ve Iletişim Kültürü Dergisi, 3(8), 16-25.

Kurtbaş, İ. (2016). Marka yönetimi ve başarılı markanın yarar ve etkileri. Karadeniz Uluslararası Bilimsel Dergisi, 32(32), 75-98.

Lam, S. Y., Shankar, V., Erramilli, M. K. ve Murthy, B. (2004). Customer value, satisfaction, loyalty, and switching costs: an illustration from a business-to-business service context. Journal of the Academy of Marketing Science, 32(3), 293-311.

Lewiss, J. ve Weigart, A. (1985). Trust as social reality, Social Forces, 65, 967-985.

Macdonald, E. K. ve Sharp, B. M. (2000). Brand awareness effects on consumer decision making for a common, repeat purchase product: A replication. Journal of Business Research, 48(1), 5-15.

Marangoz, M. (2007). Tüketicilerin marka fonksiyonu algılamaları ile satın alma sonrası davranışları arasındaki ilişki, Dokuz Eylül Üniversitesi İktisadi ve İdari Bilimler Fakültesi Dergisi, 21(2), 87-96.

Morrison, S. ve Crane, F. G. (2007). Building the service brand by creating and managing an emotional brand experience. Journal of Brand Management, 14(5), 410-421.

Nguyen, N. ve Leblanc, G. (2001). Corporate image and corporate reputation in customers' retention decisions in services. Journal of Retailing and Consumer Services, 8(4), 227-236.

Odabaşı, Y. (2015). Satış ve pazarlamada müsteri ilişkileri yönetimi (CRM). AURA Kitapları. Ankara.

Onurlubaş, E. ve Şener, T. (2016). Markalı ürün ve ilgili tüketici düşüncelerinin belirlenmesi üzerine bir araştırma. Selcuk Üniversitesi Sosyal Bilimler Enstitüsü Dergisi, 35, 325-341.

Özbek, V., Koç, F. ve Doğan, Ö. (2020). Marka aşkının öncülleri ve sonuçları: Akı1lı telefon ürünü özelinde bir araştırma. Business \& Management Studies: An International Journal, 8(4), 647-684.

Özgüven, N. (2010). Marka değeri: Global markaların değerlendirilmesi. Organizasyon ve Yönetim Bilimleri Dergisi, 2(1), 141-148.

Rauyruen, P ve Miller, K. E. (2007). Relationship quality as a predictor of B2B customer loyalty. Journal of Business Research, 60(1), 21-31.

Selvi, M. S. (2007). Müsteri Sadakati. Ankara: Detay Yayıncılık.

Sönmez, F. (2010). Giyimde marka bağımlılı̆̆1 ve marka duyarlılığı: Gençler üzerine bir araştırma. Erciyes Üniversitesi Sosyal Bilimler Enstitüsü Dergisi, 1(28), 67-91.

Srinivasan, T. N. (2004). Chine and India: Economic performance, competition and cooperation: An update. Journal of Asian Economics, 15(4), 613-636.

Sürücü, L. ve Maslakçı, A. (2020). Validity and reliability in quantitative research. Business \& Management Studies: An International Journal, 8(3), 2694-2726. 
Swaen, V. ve Chumpitaz, C. R. (2008). Impact of corporate social responsibility on consumer trust, Recherce at Applications On Marketing, 23(4), 7-34.

Şimsek, G. G. ve Noyan, F. (2009). Türkiye'de cep telefonu cihazı pazarında marka sadakati için bir model denemesi. METU Studies in Development, 36(1), 121-159.

Tabachnick, B. G., Fidell, L. S. ve Ullman, J. B. (2007). Using multivariate statistics, Boston, MA: Pearson.

TUIKK (2020). Türkiye Istatistik Kurumu, Ulaşım Tarihi: 14 Haziran 2020, http://www.tuik.gov.tr/PreTablo.do?alt_id=1028.

Turhan, G. (2009). Marka yayılımına ilişkin tüketici tutumlarının oluşumunda marka bağlllığ1 ve algıllanan uyumun etkileri: Performans risk algılarının rolü. Kocaeli Üniversitesi Sosyal Bilimler Enstitüsü Dergisi, 18, 168-197.

Uludağ, G., Faiz, E. ve Çatı, K. (2018). Akıllı telefon pazarında marka imajının müşteri sadakati üzerindeki etkisinde memnuniyetin aracilık rolü. Issletme Araştırmalar Dergisi, 10(4), 575-599.

Ulusu, Y. (2016). İlgilenim. Marmara Üniversitesi Öneri Dergisi, 12(45), 569-586.

Warrington, P. ve Shim, S. (2000). An empirical investigation of the relationship between product involvement and brand commitment. Psychology \& Marketing, 17(3), 761-782.

Yener, D. (2013). Marka çağrışım unsurlarının marka kişiliği üzerine etkisi. Electronic Journal of Vocational Colleges, 3(1), 89-103.

Yetkil, E. M. (2017). Hizmet kalitesi ve marka imajınn müsteri sadakatine etkisi: bankacıllk sektöründe bir uygulama (Yüksek Lisans Tezi). Türk Hava Kurumu Üniversitesi Sosyal Bilimler Enstitüsü, Ankara.

Yükselen, C. (2006). Pazarlama ilkeler-yönetim. Ankara: Detay Yayıncilık.

Zeren, D. ve Gökdağlı, N. (2017). Marka prestiji ve marka kredibilitesinin satın alma niyeti üzerindeki etkisi. $\dot{I}_{s}$ letme ve İktisat Calismalar Dergisi, 5(2), 91-102.

\section{EXTENDED ABSTRACT}

In recent years, the increase of products and services with homogeneous and similar features has directed the businesses to differentiate on some issues or to provide their customers with different aspects in order to keep them in the competitive environment in the market (Morrison \& Crane, 2007, p. 419). Today, as in almost whole industries, the brand has a great influence on the competitive advantage of the mobile phone industry. The brand is used in competitive markets as a factor that facilitates for recognition and separation of businesses from their competitors. The fast development of technology and industrial sharing enables companies to capture the features in competing company products in a short time and develop similar features. This causes the increase of effects of more emotional and loyalty-based attitudes such as brand trust, loyalty and image as well as more utilitarian features such as price and functionality.

Young people, who make up a large part of the consumer mass, are seen as potential customers of technological products/services, especially mobile phones. Mobile phones which produced in recent years are developed and offered to the market in line with the needs and demands of young customers, depending on the market research conducted. Young people, who are potential customers, also contribute to the development of the mobile phone industry.

In this study, it was aimed to determine the effect of brand trust, image and brand loyalty on satisfaction, and the effect of satisfaction on brand loyalty and purchase intention in young adults' use of mobile phones. Since it is not possible to collect data from the entire universe in terms of time and cost, the data were collected from 749 adult young people aged 20-30 who are living in Istanbul, by convenience sampling method and by face-to-face questionnaire method. The statements in the scale are in the 5-point Likert system, ranging from 1 (Strongly Disagree) to 5 (Strongly Agree). The survey form contains a total of 33 statements.

Before testing the hypotheses, the validity and reliability of the variables were checked. In the exploratory factor analysis (EFA) conducted to test the structural validity of the variables included in the research and to determine its sub-dimensions, the principal components method in the varimax rotation axis was applied. In addition, in the confirmatory factor analysis (CFA), fit indices of different models were examined and it was determined that the research model had good fit indices.

The study focused primarily on the conceptual framework, then the research method was determined. As the research method, correlation and regression analyzes were carried out. And 9 hypotheses determined for the purpose of the research. The research is important in terms of shedding light on the effects of the characteristics of brands such as image, trust and innovativeness on the brand loyalty and purchasing behaviors of young mobile phone users. 
The scope of this study is to determine the impact of brand trust, brand loyalty, brand image and customer brand satisfaction on brand loyalty and purchasing behavior for young consumers. In this context, it is determined that relationship between brand antecedents and the decisions of young consumers to choose the same mobile phone brand again. Also, the effect of factors that make up the brand antecedents and consequences (brand trust, brand loyalty, brand image, customer brand satisfaction) on the decisions to choose the same cell phone brand again, was tried to be revealed.

With this study, it is expected that researchers and practitioners will be given an idea about the effects of brand antecedents' factors on brand loyalty and purchasing behavior, and the mediation role of customer brand satisfaction, on topics that can help in brand creation. In addition to contributing to the literature, the study also offers suggestions for businesses that will take/act as a practitioner in brand creation or development. Businesses need to consider that they should focus on the intangible benefits as well as the functional or physical benefits of their products/services. The brand perception created by customers is important both for the sales and revenues of the business and for its place in the market.

The study is expected to be a guide for future studies. The sample of the study is limited to young consumers, and the subject of research is limited to mobile phone brands and their usage. For this reason, a specific model has been created for the mobile phone industry and data was collected from young mobile phone users. It is considered that the application of future studies on different industries and consumer groups will provide an opportunity to make more detailed evaluations on the subject. 